Acta vet. scand. $1970,11,341-360$.

From the National Veterinary Institute, Stockholm and the Research Station of the Veterinary Institute, Skara, Sweden.

\title{
COMPARATIVE STUDIES \\ ON THE GAMMAGLOBULIN LEVEL IN SERA OF MARKET CALVES IN RELATION TO .THEIR HEALTH*)
}

\author{
By \\ B. Hurvell and H. Fey ${ }^{\star \star}$ )
}

The antibodies which are passively transmitted from cow to calf via colostrum are absolutely essential for the protection of the newly born calf during the great risk period of the first days and weeks $(3,5,11,12,14,15,20,21)$. The strength of this protection as revealed by the serum gammaglobulin level in the calf depends quantitatively on a number of factors, one of which is the immunity status of the dam and another the ability of the calf to resorb the maternal antibodies from colostrum (8).

Considerable variations have been reported in the serum gammaglobulin levels for calves from different countries. Fey \& Margadant (10) showed that five out of 46 healthy calves in Switzerland which had received colostrum had more or less marked hypogammaglobulinaemia. Fey (9) also reported that 138 out of 149 calves which had died of colisepticaemia were entirely lacking in or had too small quantities of gammaglobulins in their serum.

Variations are also reported from England with respect to serum gammaglobulin levels for 52 calves which were permitted

*) This study was facilitated by grant from "Fonden för främjandet av forsknings- och försöksverksamheten på jordbrukets område" and by assistance of the society of the Swedish Farmers Meat-Marketing Association in Uppsala.

${ }^{\star \star}$ ) Professor Dr. Hans Fey, Head of the Institute of Veterinary Bacteriology, University of Berne, Switzerland, visiting professor at the National Veterinary Institute during the summer of 1968. 
to suckle their dams during the first two days after birth and which thereby had free access to colostrum. Six calves with extremely low gammaglobulin values died of bacteraemia (25).

A similar study in Scotland reported that 53 out of 178 market calves were lacking in or had extremely low gammaglobulin values for their serum, and 20 out of these 53 died of colisepticaemia (15).

In a comparative study carried out in England concerning the gammaglobulin level in the serum of market and home-bred calves, no difference was established between the two groups (26). The study consisted of a total of 190 home-bred and 40 market calves. No gammaglobulins were to be found in the serum of 13 of them and a noticeably low gammaglobulin content was recorded in a further 29 calves. The same study also established that calves which had suckled their dams had a higher gammaglobulin content than those which had been given colostrum in a bucket.

Dam (6) found that calves in Denmark which had died in herds with colisepticaemia problems had throughout lower serum gammaglobulin levels than those surviving. At the same time it was established, however, that the average values in the control material were in close agreement with the corresponding values for those calves which had died of colisepticaemia. The author concluded that agammaglobulinaemia in two-day old calves is extremely uncommon even for those dying of septicaemia. At the same time he questioned the importance of agammaglobulinaemia and hypogammaglobulinaemia as dominating aetiological factors in colisepticaemia.

The purpose of the present study is to apply a practical and sensitive immunological method which permits the determination of the gammaglobulin level in the serum of a large number of breeding calves, and to illustrate the possible connection between the gammaglobulin level of each individual calf at the time of marketing and its health during the subsequent four weeks after marketing, as well as registering variations in gammaglobulin levels with respect to age, weight and birth month for the individual calves.

\section{MATERIAL}

The calves used in this study are partly included in the research material which in a previous study were treated with 
respect to disease frequency and the causes of its variations in market calves (19).

During a period of one year ( $1 / 31965-28 / 2$ 1966) blood samples were taken from every calf marketed via a local society of the Swedish Farmers Meat-Marketing Association. The blood samples were taken from the calves' V. jugularis, and serum from the respective samples was removed and stored at $-25^{\circ} \mathrm{C}$ while awaiting the gammaglobulin investigation. All the calves, which almost without exception belonged to the SRB-breed, were given identity markings and were weighed in connection with the blood sampling.

Totally 5053 calves were examined. Information as to age at the time of marketing was available for about $1 / 4$ of the calves. In view of the fact that the information lacking is randomly distributed, the available dates may however be regarded as representative for the whole material. The age of the calves included in the statistical treatment varied from three to 31 days, but the majority of the calves were between 10 and 21 days old. Written information was requested from every buyer as to the state of health of the calves during the first four weeks after marketing. Observed symptoms were described by the livestock owner. Calves which died were sent for necropsy to the National Veterinary Institute, Stockholm. They were subjected to bacteriological, parasitological and in some cases virological examination.

If all of the calves purchased as one lot became ill and showed the same symptoms this was classed as "herd disease". It should be pointed out that this concept does not include already existing sick animals in the herd. Any other individual sickness of the marketed calves was classed as "sporadic disease". This latter group also included cases in which only one calf was bought and fell ill.

Of the total 5053 serum samples which were examined with respect to serum gammaglobulin content, 3901 were identifiable with complete information as to state of health, age, weight etc. and could therefore be included in the final material. The chisquare test was used in the statistical calculations.

\section{METHODS}

Since Ouchterlony (22) published his qualitative method for antigen-antibody reactions by means of double diffusion in agar- 
gel, a number of refinements of the technique have been developed for quantitative determination $(4,7,13,17,23,27,29)$. The technique of immunoprecipitation was most suitable for the present study in view of its sensitivity and assured rapid processing of a large amount of samples. It was possible to reduce the use of antiserum to a minimum by means of microtechniques on slides as described below, this being a definite advantage when standardizing the technique. This technique permitted the utilisation of a single antiserum obtained from a single rabbit for all of the calves, comprising a total of about 5000 examinations.

Preparation of bovine gammaglobulin. The gammaglobulin was prepared from a pool of a large number of cattle sera using ion exchange chromatography on DEAE-Sephadex A-50 with $0.01 \mathrm{M}$ phosphate buffer and $\mathrm{pH} 6.5$ (2).

Preparation of antibovine gammaglobulin. Bovine gammaglobulin was injected into rabbits weighing on an average $3 \frac{1}{2} \mathrm{~kg}$ according to the following schedule:

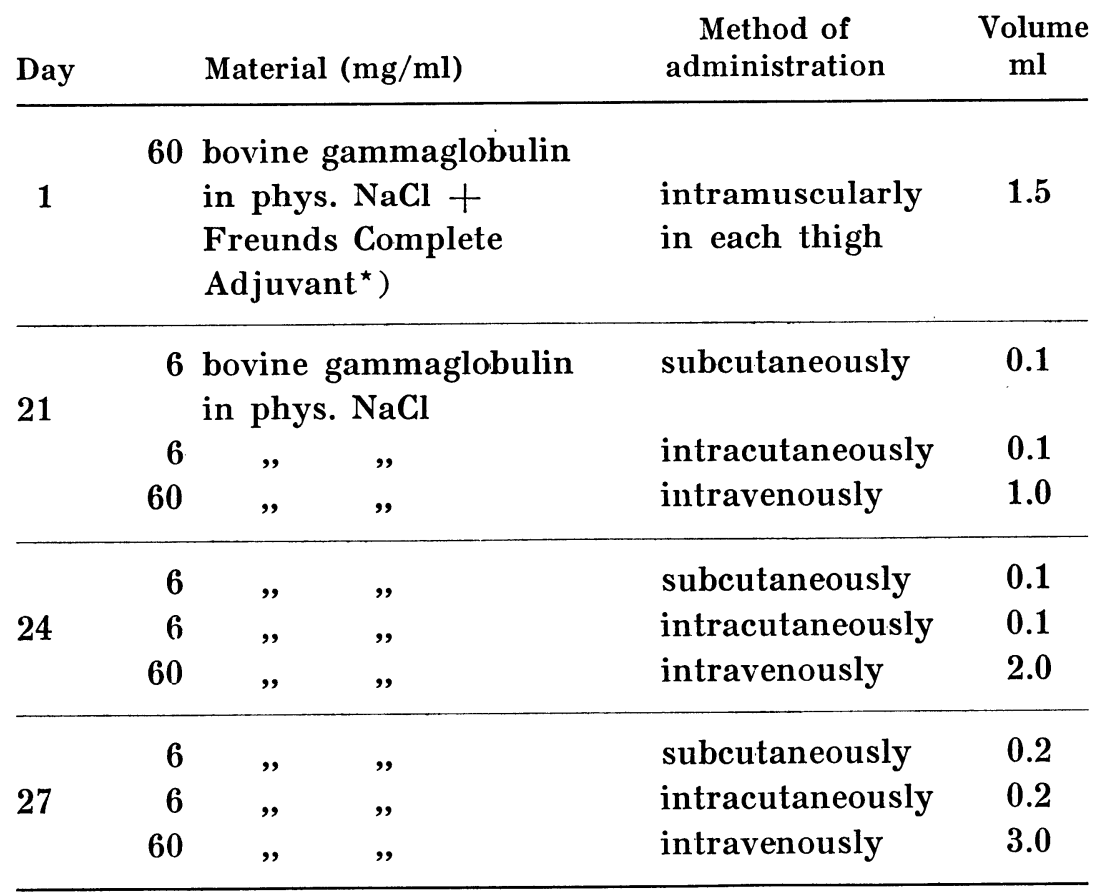

*) Emulsion of equal parts of the $6 \%$ protein solution in phys. $\mathrm{NaCl}$ and Freunds Complete Adjuvant (Difco Laboratories, Detroit, Michigan). 
A week after the final injection the rabbits were bled to death under sterile conditions.

Control of the antibovine gammaglobulin serum. The specificity and purity of the prepared antigammaglobulin were tested by means of immunoelectrophoresis (24) and immunodiffusion tests (28) (Fig. 1). Nonspecific antibodies were absorbed by

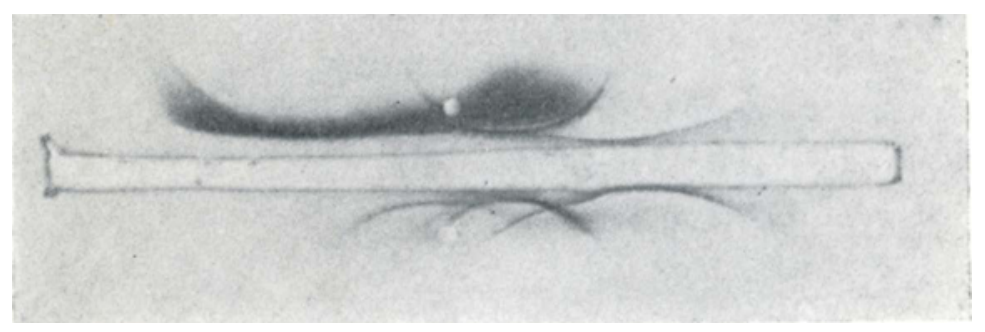

Slide no. 1

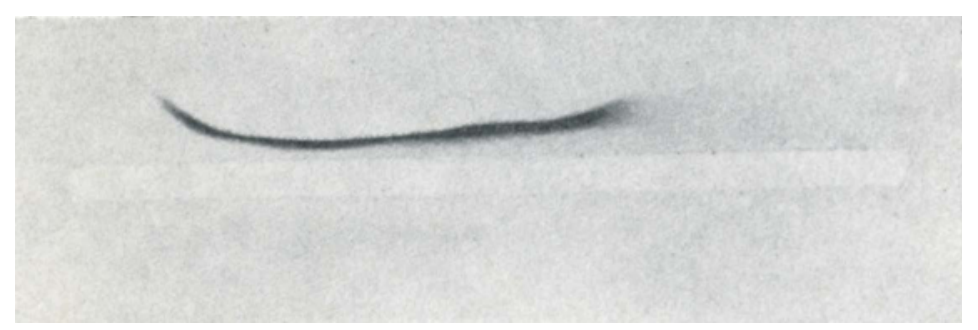

Slide no. 2

F i g u r e 1. Immunoelectrophoregram, anode to the right.

Slide no. 1

Scale $1.3: 1.0$.

Top well: Bovine serum.

Bottom well: Serum from a colostrum-deprived newborn calf.

Antibody trench: The prepared rabbit antibovine gammaglobulin before absorption.

Slide no. 2

Top and bottom well: As above.

Antibody trench: The prepared rabbit antibovine gammaglobulin after absorption.

mixing $50 \mathrm{ml}$ of the antiserum and $5 \mathrm{ml}$ serum from a newborn calf which had not received colostrum and which was agammaglobulinaemic. This mixture was preserved at $4^{\circ} \mathrm{C}$ for one month. Repeated testing by means of immunoelectrophoresis showed that the antiserum after absorption reacted specifically against the gammaglobulin fraction in bovine serum (Fig. 1). The absorbed antiserum was compared and standardized according to 
Fey et al. (13) by means of careful titrations and dilutions against a pure bovine gammaglobulin preparation and a standardized antigammaglobulin serum.

Preparing of slides for the immunoprecipitation. Two $\mathrm{ml}$ of $1.5 \%$ agar (Noble Difco) in phosphate buffered phys. $\mathrm{NaCl}$ (pH 6.4) were poured on each slide; these being placed on an absolutely horizontal table. An evenly spread agar layer about $1 \mathrm{~mm}$ thick was obtained on the slides. A pattern with five holes of $2 \mathrm{~mm}$ diameter and $3 \mathrm{~mm}$ apart were punched out by a hypodermic needle connected to vacuum (Fig. 2). The slides were then placed in a humid chamber.

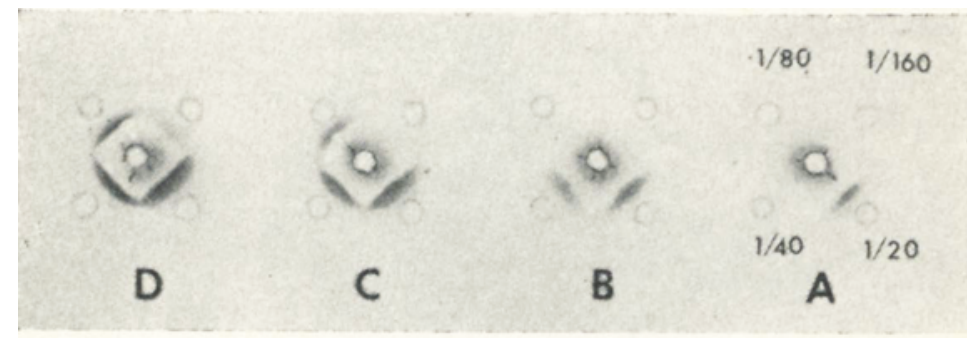

Fig u r e 2. Double diffusion in gel. Scale $1.3: 1.0$.

Central wells: Rabbit antibovine gammaglobulin.

Perifer wells: Dilutions of serum from four calves (A, B, C, D) with the gammaglobulin level of 1/20,1/40,1/80 and 1/160.

Examination of the serum samples. All dilutions were performed using Swedmyr pipette dispenser (Kifa Ltd., Stockholm) with the replacement of pipettes at each stage of dilution. The dilutions $1 / 20,1 / 40,1 / 80,1 / 160$ of the calf sera which were to be investigated were placed in the four peripheral reservoirs. The absorbed and standardized antibovine gammaglobulin serum was placed in the central reservoir (Fig. 2). Thin disposable glass capillaries were used for filling. Each reservoir contained $3.1 \pm$ $0.2 \mu \mathrm{l}$, and an extremely constant filling of the basins could be obtained by means of fixed oblique lighting and the study of light reflections. The slides were preserved for $24 \mathrm{hrs}$. for diffusion precipitation in a humid chamber. As controls, slides with known dilutions were used.

By means of magnification and in an obliquely falling light the final titer was registered for each of the calves being examined, i.e. the highest dilution of the serum which gave a visible 
precipitation line. The gammaglobulin content was expressed on the following scale $<1 / 20,1 / 20,1 / 40,1 / 80, \geq 1 / 160$. Every reading was performed three times under the same standard conditions. Drying and staining with amido-black was carried out in some cases after the readings.

On checking the sensitivity of the methodology described above it was found that quantities as small as $40-80 \mu \mathrm{g} / \mathrm{ml}$ of bovine gammaglobulin could be determined.

Control experiments were performed using Kjeldahl-determination of the protein nitrogen content of the reference solutions. The conventional factor of 6.25 was used in order to convert the nitrogen value to protein content.

\section{RESULTS}

In the material of the 3901 calves, on which this study is based, signs of diseases were observed and reported during the first four weeks for a total of $684(17.5 \%)$. Of these $329(8.4 \%)$ were attacked by herd disease and $355(9.1 \%)$ by sporadic disease. Necropsies including bacteriological and parasitological studies were performed on 74 calves. The mortality rate in the whole material was $2.5 \%$. The most common disease symptom was diarrhoea, both with regard to herd and sporadic disease. As can be seen in Table $177.7 \%$ and $58.3 \%$ of the calves respectively suffered from diarrhoea. Symptoms concerning the respiratory organs were reported for $40.4 \%$ of the calves suf-

Table 1. Distribution of disease symptoms.

\begin{tabular}{lrr}
\hline & $\begin{array}{c}\text { Number of } \\
\text { calves }\end{array}$ & $\%$ \\
\hline Sporadic disease & & \\
Diarrhoea & 244 & 68.7 \\
Diarrhoea, coughing and nasal discharge & 32 & 9.0 \\
Coughing and nasal discharge & 19 & 5.4 \\
Other symptoms & 60 & 16.9 \\
& & \\
Herd disease & 156 & 47.4 \\
Diarrhoea & 36 & 10.9 \\
Diarrhoea, coughing and nasal discharge & 133 & 40.4 \\
Coughing and nasal discharge & 4 & 1.2 \\
Other symptoms & & \\
\hline
\end{tabular}


fering from herd disease and only $5.4 \%$ of those which were sporadically ill.

The distribution of causes of death in the calves according to the results of the post-mortem examinations is shown in Fig. 3. The major cause of death $(33.8 \%)$ was gastro-enteritis. Septicaemia and pneumonia were the apparent cause of death in $21.6 \%$ and $20.3 \%$ of the cases respectively. Other ascertained causes of death include ruminal indigestion in $14.9 \%$, mucosal disease and coccidiosis in $4.1 \%$ and $2.7 \%$ respectively. Most of the calves died during the second week after marketing.

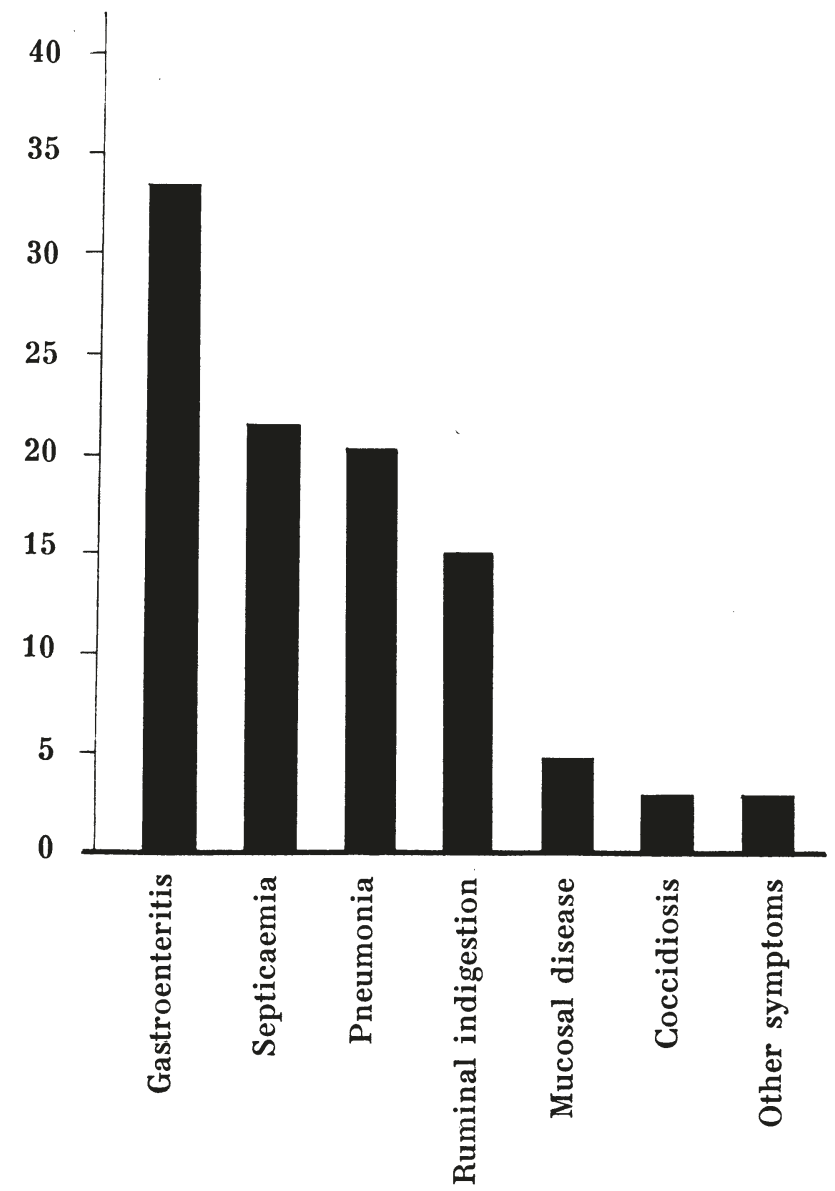

Figure 3. Percentage distribution of causes of death for 74 necropsied calves according to Jönsson \& Swahn (19). 
The bacteriological diagnosis in the 13 verified cases of septicaemia was :

Pasteurella multocida

6 cases

Escherichia coli

4 cases

Clostridium welchii

2 cases

Diplococcus pneumoniae

1 case

In addition, the following local infections were established:

Corynebacterium pyogenes

7 cases

Escherichia coli

5 cases

Pasteurella multocida

2 cases

$\beta$-haemolytic streptococci

1 case

The gammaglobulin level of the healthy calves is shown in Fig. 4. The titer values on the abscissa refer to the dilution of

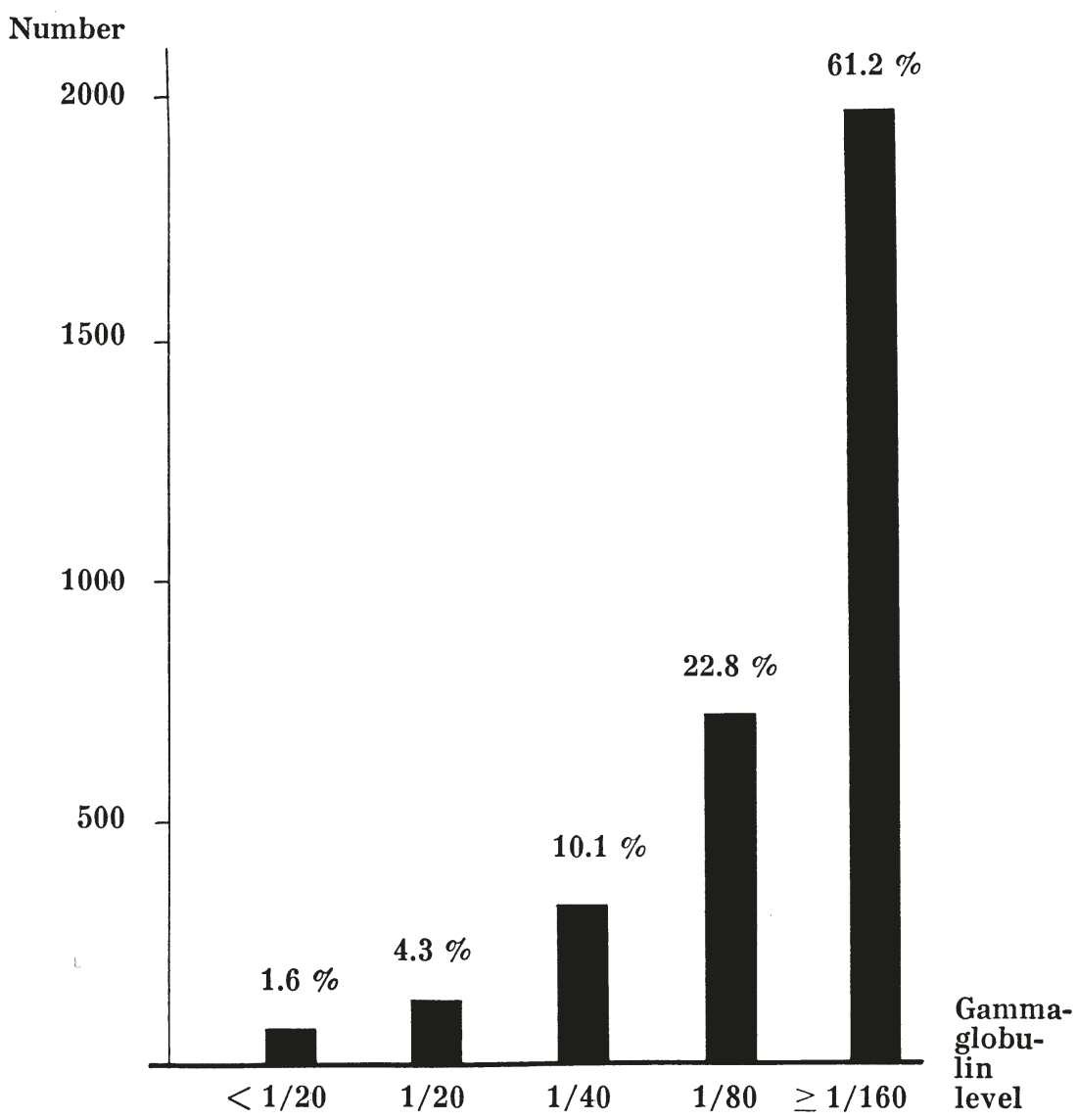

F ig u r e 4. Gammaglobulin level of the healthy calves. 
the respective sera. The border between a- and hypogammaglobulinaemia on the one hand and normo- and hypergammaglobulinaemia on the other has been set between the titer $1 / 40$ and 1/80 (11). Sixteen $\%$ of the calves had a- and hypogammaglobulinaemia according to this definition.

The term "sick calves" included those suffering from the symptom combinations shown in Table 1 . The term "other symptoms" includes skin lesions, locomotion difficulties, dullness, anorexia, etc.

No significant difference was established with respect to the gammaglobulin level in calves with sporadic and herd disease respectively.

The relationship between gammaglobulin level and the disease symptoms reported is shown in Table 2. Calves with diarrhoea

T a b l e 2. Gammaglobulin level for the total number of the calves with disease symptoms.

\begin{tabular}{l|rrrr}
\hline $\begin{array}{l}\text { Gammaglobulin } \\
\text { Disease } \\
\text { symptom }\end{array}$ & & & & \\
level & $<1 / 40$ & $1 / 40$ & $1 / 80$ & $\geq 1 / 160$ \\
\hline $\begin{array}{l}\text { Diarrhoea } \\
\text { Diarrhoea, coughing and nasal } \\
\text { discharge }\end{array}$ & 30 & 60 & 83 & 227 \\
$\begin{array}{l}\text { Coughing and nasal discharge } \\
\text { Other symptoms }\end{array}$ & 5 & 7 & 18 & 38 \\
\hline
\end{tabular}

$\chi^{2}=7.30 \quad$ not significant.

as the only symptom and the group of calves with "other symptoms" had a lower gammaglobulin level with a somewhat greater frequency than the two other groups. These differences are not, however, statistically significant.

In Table 3 the relationship is shown between gammaglobulin level and the various causes of death in the necropsied calves. Seventy-five $\%$ of the calves which died of septicaemia had a subnormal gammaglobulin level and could be regarded as hypogammaglobulinaemic. The corresponding figures for calves dying of pneumonia and gastroenteritis were $40 \%$ and $28 \%$ respectively. Chi-square analysis of these three groups showed that the differences were statistically significant. 
T a b l e 3. Gammaglobulin level and cause of death of the necropsied calves.

\begin{tabular}{|c|c|c|c|c|}
\hline Cause of death & $<1 / 40$ & $1 / 40$ & $1 / 80$ & $\geq 1 / 160$ \\
\hline${\text { Gastroenteritis }{ }^{*} \text { ) }}$ & 1 & 6 & 5 & 13 \\
\hline Pneumonia $^{*}$ ) & 1 & 5 & 3 & 6 \\
\hline Septicaemia ${ }^{*}$ ) & 7 & 5 & 2 & 2 \\
\hline Ruminal indigestion & & 1 & 3 & 7 \\
\hline Coccidiosis & & & 2 & \\
\hline Mucosal disease & & & 2 & 1 \\
\hline Chronic umbilical abscess & & 1 & & \\
\hline Anaemia & & & & 1 \\
\hline
\end{tabular}

*) $\chi^{2}=15.515^{*}$

$\mathbf{P}=98.3 \%$

The sick calves had on the whole lower gammaglobulin content than the healthy ones, but the differences are not sufficiently great to be statistically significant (Table 4 ).

'T a b l e 4. Gammaglobulin level in healthy and sick calves.

\begin{tabular}{|c|c|c|c|c|c|}
\hline \multirow{2}{*}{$\begin{array}{l}\text { Gammaglobulin } \\
\text { level }\end{array}$} & \multicolumn{2}{|c|}{ Healthy } & \multicolumn{2}{|c|}{ Sick } & \multirow{2}{*}{$\begin{array}{c}\text { Morbidity } \\
\%\end{array}$} \\
\hline & number & $\%$ & number & $\%$ & \\
\hline$<1 / 20$ & 51 & 1.6 & 17 & 2.5 & 25.0 \\
\hline $1 / 20$ & 137 & 4.3 & 34 & 5.0 & 19.9 \\
\hline $1 / 40$ & 326 & 10.1 & 89 & 13.0 & 21.4 \\
\hline $1 / 80$ & 733 & 22.8 & 150 & 21.9 & 17.0 \\
\hline$\geq 1 / 160$ & 1970 & 61.2 & 394 & 57.6 & 16.7 \\
\hline Total & 3217 & 100.0 & 684 & 100.0 & \\
\hline
\end{tabular}

$\chi^{2}=9.08$ not significant.

The sick calves which survived had a significantly higher gammaglobulin content than those which died and were necropsied. The mortality risk is considerably greater for calves with low gammaglobulin levels (Table 5).

An even more significant difference with respect to serum 
T a b l e 5. Gammaglobulin level in sick surviving and dead necropsied calves.

\begin{tabular}{lrrrrrr}
\hline \multirow{2}{*}{$\begin{array}{l}\text { Gammaglobulin } \\
\text { level }\end{array}$} & \multicolumn{2}{c}{ Surviving } & & \multicolumn{2}{c}{ Necropsied } & \multirow{2}{*}{ Mortality } \\
\cline { 2 - 3 } & number & $\%$ & & number & $\%$ & $\%$ \\
\hline$<1 / 40$ & 42 & 6.9 & & 9 & 12.2 & 17.7 \\
$1 / 40$ & 71 & 11.6 & & 18 & 24.3 & 20.2 \\
$1 / 80$ & 133 & 21.8 & & 17 & 23.0 & 11.3 \\
$\geq 1 / 160$ & 364 & 59.7 & & 30 & 40.5 & 7.6 \\
\hline Total & 610 & 100.0 & & 74 & 100.0 & \\
\hline
\end{tabular}

$\chi^{2}=14.87^{\star \star}$

$\stackrel{P}{\mathrm{P}}=\mathbf{9 9 . 8} \%$

gammaglobulin level was to be found between the healthy and the dead calves subject to necropsy as is apparent in Table 6. The mortality risk is more than three times as great in the two groups which have the lowest gammaglobulin content compared with that with the highest content.

T a bl e 6. Gammaglobulin level in healthy and dead necropsied calves.

\begin{tabular}{lrrrrrr}
\hline \multirow{2}{*}{$\begin{array}{l}\text { Gammaglobulin } \\
\text { level }\end{array}$} & \multicolumn{2}{c}{ Healthy } & & \multicolumn{2}{c}{ Necropsied } & \multirow{2}{*}{ Mortality } \\
\cline { 2 - 3 } & number & $\%$ & & number & $\%$ & \\
\hline$<1 / 40$ & 188 & 5.9 & & 9 & 12.2 & \\
$1 / 40$ & 326 & 10.1 & & 18 & 24.3 & 4.6 \\
$1 / 80$ & 733 & 22.8 & & 17 & 23.0 & 5.2 \\
$\geq 1 / 160$ & 1970 & 61.2 & & 30 & 40.5 & 2.3 \\
\hline Total & 3217 & 100.0 & & 74 & 100.0 & \\
\hline
\end{tabular}

$\chi^{2}=23.86^{\star \star}$

$\mathrm{P}=99.997 \%$

The gammaglobulin level of the calves in the different weight categories is shown in Table 7. In the two lightest weight categories the proportion of calves with hypogammaglobulinaemia was more than twice as great as in the two heaviest categories. With increasing weight the frequency of hypogammaglobulinaemia decreases. This tendency is statistically significant. 
T a b l e 7. Distribution of gammaglobulin levels in the material as a whole for different weights of calves at the time of marketing.

\begin{tabular}{|c|c|c|c|c|c|}
\hline (level & $<1 / 40$ & $1 / 40$ & $1 / 80$ & $\geq 1 / 160$ & $\begin{array}{l}\text { Hypogamma- } \\
\text { globulin- } \\
\text { aemia } \\
\%\end{array}$ \\
\hline$\leq \mathbf{3 5}$ & 16 & 21 & 36 & 81 & 24.0 \\
\hline $36-40$ & 74 & 122 & 222 & 533 & 20.6 \\
\hline $41-45$ & 88 & 147 & 322 & 865 & 16.5 \\
\hline $46-50$ & 48 & 80 & 178 & 522 & 15.5 \\
\hline $51-55$ & 8 & 32 & 100 & 269 & 9.8 \\
\hline$\geq 56$ & 1 & 12 & 29 & 95 & 9.5 \\
\hline Total & 235 & 414 & 887 & 2365 & \\
\hline
\end{tabular}

$\chi^{2}=100.3^{\star \star \star}$

$\mathrm{P}>99.999 \%$

Table 8 contains the distribution of gammaglobulin levels for different age categories. It is evident that there is no significant relation between gammaglobulin level and age.

T a ble 8. Distribution of gammaglobulin levels in the material as a whole for different ages of calves at the time of marketing.

\begin{tabular}{l|rrrr|c}
\hline $\begin{array}{l}\text { Gammaglobulin } \\
\text { level } \\
\text { days }\end{array}$ & & & & & $\begin{array}{c}\text { Hypogamma- } \\
\text { globulin- } \\
\text { aemia } \\
\%\end{array}$ \\
\hline $3-12$ & $<1 / 40$ & $1 / 40$ & $1 / 80$ & $\geq 1 / 160$ & \\
$13-18$ & 15 & 16 & 39 & 123 & 16.1 \\
$>19$ & 25 & 37 & 87 & 261 & 15.1 \\
\hline Total & 20 & 43 & 122 & 181 & 17.2 \\
\hline
\end{tabular}

$\chi^{2}=11.96$ not significant.

Table 9 shows a significant seasonal difference in the gammaglobulin level of calves born in different months. A somewhat greater frequency of hypogammaglobulinaemia occurs in calves which are born between November and June. The highest frequency is to be found in calves born during March and April and the lowest in those born during September and October. 
T a b l e 9. Distribution of gammaglobulin levels in the material as a whole in respect of the birth month of the calves.

\begin{tabular}{l|ccccc}
\hline & & & & & $\begin{array}{c}\text { Gammaglobulin } \\
\text { level }\end{array}$ \\
$\begin{array}{l}\text { Birth } \\
\text { month }\end{array}$ & $<1 / 40$ & $1 / 40$ & $1 / 80$ & $\geq 1 / 160$ & $\begin{array}{c}\text { Hypogamma- } \\
\text { globulin- } \\
\text { aemia } \\
\%\end{array}$ \\
\hline Jan.-Feb. & 26 & 47 & 142 & 274 & 14.9 \\
March-April & 52 & 91 & 152 & 425 & 19.9 \\
May-June & 42 & 62 & 139 & 368 & 17.0 \\
July-Aug. & 42 & 60 & 135 & 438 & 15.1 \\
Sept.-Oct. & 41 & 61 & 134 & 152 & 12.9 \\
Nov.-Dec. & 33 & 74 & 179 & 335 & 17.2 \\
\hline Total & 236 & 395 & 881 & 2392 & \\
\hline
\end{tabular}

$\chi^{2}=69.31^{\star \star \star ~}$

$\mathrm{P}>99.999 \%$

\section{DISCUSSION}

In the study presented the gammaglobulin level has been determined for all calves marketed by the intermediary of a local society of the Swedish Farmers Meat-Marketing Association in central Sweden during a period of one year. As the material consisted of about $55 \%$ of all of the calves sold, which were randomly distributed within the area in question, it should be representative.

A surprisingly large percentage of the healthy calves had a gammaglobulin content below the lower limit as proposed by Fey et al. (11); $514(16.0 \%)$ of the calves which showed no signs of illness can be regarded as a- or hypogammaglobulinaemic. A corresponding figure of $11 \%$ has been reported by Fey et al. (11) in a study of 46 calves showing no disease symptoms. The calves in the present study were somewhat older, the majority were between 10 and 21 days old. In the Swiss material none of the 46 calves was over one week old. Gay et al. (16) reported that of 178 calves less than four days old, $53(29.8 \%)$ had noticeably too low gammaglobulin values. It should be pointed out that in this Scottish examination the quantitative serum gammaglobulin study was performed using a modification of Aschaffenburg's colorimetric determination (1), which makes a direct comparison between this and the Swiss and Swedish studies more difficult.

The various endogenous and exogenous factors which are important for the serum gammaglobulin level in the young non- 
immune calf will not be dealt with here. The large proportion of calves with too low gammaglobulin values clearly points to the fact that there may be deficiencies in the ways of breeding calves with regard to providing maximal opportunities for the resorption of gammaglobulin from colostrum. Many of the diarrhoeas reported were of a mild and transient nature the aetiology of which has not primarily been infectious but often arisen through overfeeding. Jönsson \& Swahn (19) reported that morbidity at excessive milk-feeding is almost three times greater than for normal milk-feeding. Smith (25) considers that diarrhoeas arising in calves despite the fact that they have received colostrum are not the result of infection but are in fact caused among other things by deficiencies in the technical feeding arrangements. In the present work no correlation between low gammaglobulin level and diarrhoea could be confirmed.

The main causes of death for necropsied calves were gastroenteritis, septicaemia and pneumonia. There is a clearly increasing frequency of hypogammaglobulinaemia for calves whose cause of death is included in these groups. Twelve out of 16 , i.e. $75 \%$ of the calves which died of septicaemia, had gammaglobulin values below the normal and of these four had been agammaglobulinaemic. Two of this latter group died of colisepticaemia and one each of pasteurella- and diplococcus-septicaemia respectively. There is thus a connection between a low gammaglobulin level and septicaemia, which has also been confirmed in previous studies $(11,15)$. More than one fourth of the calves which died of gastroenteritis had low gammaglobulin values. As also $16 \%$ of the healthy calves had low gammaglobulin values no definite tendency, however, emerges from the results. This, therefore, should only be interpreted as a suggestion of a possible relationship between gammaglobulin level and mortality in enteritis not associated with septicaemia. In their study of 178 calves Gay et al. (15) discovered similar tendencies. The material with regard to death in pneumonia is limited and has failed to reveal a definite relationship to the gammaglobulin level.

Jönsson \& Swahn (19) found that morbidity was two to three times as great in light as compared with heavy calves and that there was a significant correlation between risk of illness and weight of the calves at the time of marketing. The age of the calves does not appear to be of any great importance for risk of illness during the first four weeks after marketing. 
It is interesting to note in this connection the correlation between weight and level of gammaglobulin. The noticeably increased frequency of calves with low gammaglobulin values in the lower weight-classes may point to a possible connection with or explanation of the greater risk for diseases and death of these calves. The available literature contains no directly comparable studies dealing with this relationship. Weight is for obvious reasons to some extent a function of age. The available material shows, however, no clear age dependancy. Age does not appear to be of any great importance as a factor influencing the level of gammaglobulin in the calves examined, whose ages varied from three to 31 days.

Experiments with mice and rats (18) have shown that corticosteroids may block the resorption of gammaglobulin. In Scotland, Gay et al. (16) have established that low gammaglobulin values were more common in calves which were born during the winter and spring compared with those born during the rest of the year. According to a theory concerning this seasonal variation in gammaglobulin levels in calves put forward by Gay et al. (15) the cold periods of the year involve an element of stress for the animals which leads to increased secretion of adrenaline. This could influence the resorption of the colostrum's gammaglobulin. They have shown in this connection that during the cold period of the year most calves lose the ability to resorb globulins via the intestine already within 9-12 hrs. and in some cases within 4-6 hrs.

The present material shows a noticeably higher frequency of hypogammaglobulinaemia in calves born during the months of March and April and the lowest frequency for those born in September and October. This seasonal variation is in good agreement with the results reported by Gay et al. (16) and the results regarding the variations in disease frequencies obtained by Jönsson \& Swahn (19). A significant increase in morbidity was apparent during the months of December-June when compared with the rest of the year. This agreement concerning seasonal variations suggests a possible relationship between morbidity and gammaglobulin level.

\section{ACKNOWLEDGMEN'T}

We gratefully acknowledge the valuable assistance of fil.kand. Jan Grandell at the Institute of Mathematical Statistics, Stockholm University. 


\section{REFERENCES}

1. Aschaffenburg, R.: The nutritive value of colostrum for the calf. 3. Changes in the serum protein of the newborn calf following the ingestion of small quantities of the non-fatty fraction. Brit. J. Nutr. 1949, 3, 200-204.

2. Baumstark, J. S., R. J. Laffin \& W. A. Bardawil: A preparative method for the separation of $7 \mathrm{~S}$ gammaglobulin from human serum. Arch. Biochem. 1964, 108, 514-522.

3. Baier, W., K. Walser \& I. Rüsse: Über die bakterielle Kontamination des Kalbes während der Geburt und in den ersten Lebensstunden. (Bacterial contamination of calves during birth and the first hours of life). Tierärztl. Umsch. 1967, $22,118,121-124$.

4. Crowle, A. J.: Four modifications of the micro agar diffusion precipitin test. J. Lab. clin. Med. 1960, 55, 593-604.

5. Dam, A.: Værdien af colostrum ved opdrætning af kalve. (The importance of giving calves colostrum). Medlemsbl. danske Dyrlægeforen. 1965, 48, 197-200.

6. Dam, A.: Studies on the gammaglobulin levels in sera of calves from herds with colisepticaemia as a problem, and some investigations on the content of specific antibodies in colostrum. Nord. Vet.-Med. 1968, 20, 449-457.

7. Feinberg, J. G.: A new quantitative method for antigen-antibody titrations in gels. Nature (Lond.) 1956, 177, 530-531.

8. Fey, H.: Entstehung und Verhütung der Coli-Infektionen der Kälber. (Pathogenesis and prophylaxis of coliform infections in calves). Zbl. Vet.-Med. Reihe B, 1966, 13, 175-179.

9. Fey, H.: Die Bedeutung des Gammaglobulins für das neugeborene Kalb. (The importance of gammaglobulins for the newborn calf). Int. tierärztl. Arbeitsgemeinschaft Tierernährung. Symposium, Salzburg 1967, 17-28.

10. Fey, H. \& Anita Margadant: Hypogammaglobulinämie bei der Colisepsis des Kalbes. (Hypogammaglobulinaemia in calves with E. coli septicaemia). Path. et Microbiol. (Basel) 1961, 24, 970-976.

11. Fey, H. \& Anita Margadant: Zur Pathogenese der Kälber-Colisepsis. IV. Agammaglobulinämie als disponierender Faktor. (Pathogenesis of E. coli septicaemia in calves. IV. Agammaglobulinaemia as a predisposing factor). Zbl. Vet.-Med. $1962,9,653-663$.

12. Fey, H. \& G. Hunyady: Zur Substitutionsprophylaxe mit Colostrum-Poolserum bei Agammaglobulinämischen Kälbern. (On substitution prophylaxis with colostrum-poolserum for agammaglobulinemic calves). Berl. Münch. tierärztl. Wschr. $1962,75,466-467$. 
13. Fey, H., J. Nicolet, R. v. Fellenberg \& A. Margadant: Immunologische, serologische und immunochemische Methoden zum Nachweis der Agammaglobulinämie des Kalbes. (Immunological, serological and immuno-chemical methods to demonstrate agammaglobulinaemia in the calf). Zbl. Vet.Med. Reihe B, 1964, 11, 584-602.

14. Fisher, E. W.: Contribution to a debate at B.V.A. Congress, Edinburgh 1965. Vet. Rec. 1965, 77, $1482-1484$.

15. Gay, C. C., N. Anderson, E. W. Fisher \& A. D. Mc Ewan: Gammaglobulin levels and neonatal mortality in market calves. Vet. Rec. 1965, 77, 148-149.

16. Gay, C. C., N. Anderson, E. W. Fisher \& A. D. Mc Ewan: Seasonal variations in gammaglobulin levels in neonatal market calves. Vet. Rec. $1965,77,994$.

17. Gell, P. G. H.: The estimation of the individual human serum proteins by an immunological method. J. clin. Path. 1957, 10, 67-71.

18. Halliday, R. J.: The effect of steroid hormones on the absorption of antibody by the young rat. J. Endocr. 1959, 18, 56-66.

19. Jönsson, G. \& O. Swahn: Morbiditet och mortalitet hos inköpta kalvar. (Morbidity and mortality in marketing calves). Nord. Vet.-Med. 1968, 20, 377-395.

20. Mayr, A., G. Wizigmann, I. Wizigmann \& Th. Schliesser: Untersuchungen über infektiöse Kälbererkrankungen während der Neugeborenen-Phase. (Studies on infectious calves in the post-natal phase). Zbl. Vet.-Med. Reihe B, 1965, 12, $1-12$.

21. Mayr, A.: Das Infektionsgeschehen während der NeugeborenenPhase der Kälber. Erkrankungen und Bekämpfung. (The mechanisms of infection in the neonatal calf. Diseases and prophylaxis). Zbl. Vet.-Med. Reihe B, 1966, 13, 165--174.

22. Ouchterlony, ö.: Double diffusion in gel technique. Progr. Allergy $1958,5,1-78$.

23. Roth, N. von: Zur semiquantitativen Erfassung der beiden Serumimmunoglobuline $\beta_{2 \mathrm{~A}}$ und $\beta_{2 \mathrm{M}}$ in Neugeborenen- und Kindesalter. (The semiquantitative estimation of the two serumimmune globulins $\beta_{2.1}$ and $\beta_{2 M}$ in the neonatal period and during childhood). Ann. paediat. (Basel) 1962, 199, $548-580$.

24. Scheidegger, J.: A micromethod of immunoelectrophoresis. Int. Arch. Allergy 1955, 7, 103--110.

25. Smith, H. Williams: Observations on the aetiology of neonatal diarrhoea (Scours) in calves. J. Path. Bact. 1962, 84, 147168.

26. Smith, H. Williams, J. A. O’Neil \& E. J. Simmons: The immune globulin content of the serum of calves in England. Vet. Rec. $1967,80,664-666$. 
27. Soothill, J. F.: Estimation of eight serum proteins by a gel diffusion precipitin technique. J. Lab. clin. Med. 1962, 59, $858-870$.

28. Wadsworth, C.: A slide microtechnique for the analysis of immune precipitates in gel. Int. Arch. Allergy 1957, 10, 355360 .

29. Wright, S. T. C.: A quantitative serumagar technique. Nature (Lond.) 1959, 183, 1282-1283.

\section{SUMMARY}

Blood samples from 3901 calves, marketed by the intermediary of a local society of the Swedish Farmers Meat-Marketing Association during the course of one year, were examined with respect to gammaglobulin levels. The age of the majority of the calves varied between 10 and 21 days. Information concerning the health of the calves and symptoms of illness within four weeks of the sale were obtained from the purchasers. Calves which died were necropsied and subjected to bacteriological, parasitological and in certain cases to virological examinations.

A description is given of the immunodiffusion technique applied.

Sixteen $\%$ of the healthy calves had a- and hypogammaglobulinaemia. A significantly greater mortality risk could be observed in sick calves with low gammaglobulin levels in their serum. When healthy and necropsied calves were conıpared, the mortality risk was thrice as great in the two groups which had the lowest gammaglobulin levels compared with the others. No significant correlation was obtained between the gammaglobulin level and morbidity risk. Nor were there any differences with regard to the gammaglobulin level between "sporadic" cases of sickness and "herd disease" cases. The most common symptom of illness in the calves was diarrhoea. No significant correlation between a low gammaglobulin level and diarrhoea could be demonstrated.

The causes of death most common in order of frequency were gastroenteritis, septicaemia and pneumonia. Seventy-five \% of the calves which died of septicaemia had hypogammaglobulinaemia.

There was no relationship between the age of the calves and the gammaglobulin level. There was, however, a very strong correlation between low weight of the calves and a high frequency of hypogammaglobulinaemia. There was also a significantly statistical correlation between the season of the year when the calves were born and their serum gammaglobulin level.

\section{SAMMANFATTNING}

Jämförande studier över gammaglobulinnivân $i$ serum och hälsotillståndet hos förmedlade livkalvar.

Blodprov från 3901 kalvar, som under ett år försåldes genom en slakteriförenings förmedling, undersöktes med avseende på gammaglobulinnivån. Åldern för majoriteten av kalvarna varierade mellan 
10 och 21 dagar. Uppgifter om kalvarnas hälsotillstånd och observerade sjukdomssymtom intill fyra veckor efter inköpet erhölls av köparna. Kalvar som dog, obducerades och blev föremål för bakteriologisk, parasitologisk och i vissa fall virologisk undersökning.

Den för undersökningen av blodproven använda immunodiffusionstekniken beskrives.

Sexton procent av de friska kalvarna var att betrakta såsom a- respektive hypogammaglobulinemiska. En signifikant ökad mortalitetsrisk förelåg hos sjuka kalvar med låg gammaglobulinnivå i serum. Vid jämförelsen mellan friska och sjuka obducerade kalvar var mortalitetsrisken tre gånger större i de två grupper, som hade lägst gammaglobulinnivå i jämförelse med de övriga. Något signifikant samband mellan gammaglobulinnivån och morbiditetsrisken fanns inte. Inte heller förelåg någon skillnad mellan sporadiskt sjuka och besättningssjuka kalvar med avseende på gammaglobulinnivån. Diarré var det vanligaste sjukdomssymtomet. Något signifikant samband mellan låg gammaglobulinnivå och diarré kunde inte utläsas av materialet.

De vanligaste dödsorsakerna var i ordning gastroenteritis, septikemi och pneumoni. Av de kalvar, som dog i septikemi, hade $75 \%$ hypogammaglobulinemi vid provtagningstillfället.

Någon relation mellan åldern hos de förmedlade kalvarna och gammaglobulinnivån kunde inte utläsas. Däremot förelåg ett mycket starkt samband mellan låg vikt hos kalvarna och hög frekvens hypogammaglobulinemi. Ett signifikant samband förelåg också mellan den tid på året, när kalvarna var födda och deras serumgammaglobulinnivå.

(Received November 10, 1969). 